\title{
Papillary squamotransitional carcinoma of cervix: a series of four cases
}

\author{
Nanda J. Patil, Dhirajkumar B. Shukla*, Mamta Bharti, Mallika Mehta
}

Department of Pathology, Krishna Institute of Medical Sciences, Karad, Satara, Maharashtra - 415110, India

\author{
Received: 09 March 2016 \\ Revised: 03 May 2016 \\ Accepted: 09 May 2016

\section{*Correspondence:} \\ Dr. Dhirajkumar B. Shukla, \\ E-mail: drshukla.patho@gmail.com
}

Copyright: (c) the author(s), publisher and licensee Medip Academy. This is an open-access article distributed under the terms of the Creative Commons Attribution Non-Commercial License, which permits unrestricted non-commercial use, distribution, and reproduction in any medium, provided the original work is properly cited.

\begin{abstract}
Background: Carcinoma of cervix is the most common cancer in Indian women and squamous cell carcinoma is the principal histologic type. Papillary Squamotransitional carcinoma is a rare and distinctive variant of squamous cell carcinoma of the uterine cervix, which differs by histology and clinical behavior from conventional squamous cell carcinoma. It shows papillary architecture with fibrovascular cores lined by multilayered atypical epithelium and is known for local recurrence and late metastasis.

Methods: 4 cases of papillary squamotransitional carcinoma of cervix were diagnosed on cervical punch biopsies. All 4 cases were analyzed histopathologically.

Results: Patients ranged from 40 years to 70 years with pain in abdomen being commonest presenting symptom. All the cases showed papillary architecture with fibrovascular cores lined by multi-layered atypical epithelium. Three cell types were observed: Clear, intermediate and basaloid.

Conclusions: Papillary Squamous Cell Carcinoma is a rare subtype of squamous cell carcinoma of cervix and is characterized by its aggressive behavior.
\end{abstract}

Keywords: Carcinoma of cervix, Papillary Squamotransitional carcinoma, Papillary Squamous Cell Carcinoma

\section{INTRODUCTION}

Carcinoma of cervix is the most common cancer in Indian women and squamous cell carcinoma is the principal histological type. Papillary squamo-transitional carcinoma is a rare and distinctive variant of squamous cell carcinoma of the uterine cervix, which differs by histology and clinical behaviour from conventional squamous cell carcinoma. ${ }^{1}$ Papillary squamo-transitional cell carcinoma can show variety of spectrum such as pure squamous, pure transitional and mixture of both. ${ }^{2}$ It shows papillary architecture with fibrovascular cores lined by multi-layered atypical epithelium and is known for local recurrence and late metastasis. ${ }^{3}$

\section{METHODS}

4 cases of papillary squamo-transitional carcinoma of uterine cervix were diagnosed on cervical punch biopsies received in Department of Pathology over a period of one year. All the biopsies were processed by routine paraffin processing and stained with haematoxylin and eosin stain.

\section{RESULTS}

Mean age among the 4 cases was 52 years with age ranging from 40 years to 70 years. The presenting symptoms were Pain in abdomen (all 4 cases), $\mathrm{P} / \mathrm{V}$ bleeding (2 cases) and P/V discharge (2 cases). Per speculum examination in all cases revealed an ulcerated growth in uterine cervix. All the cases were subjected to cervical punch biopsy. 


\section{Histopathological examinations}

Case 1

Cervical punch biopsy was taken and sent for histopathological examination. Microscopic examination revealed neoplastic cells in papillary arrangements with central fibrovascular core (Figure 1). Neoplastic cells were of both squamous and transitional type. Diagnosis of invasive papillary squamo-transitional carcinoma was given based on the microscopic features.

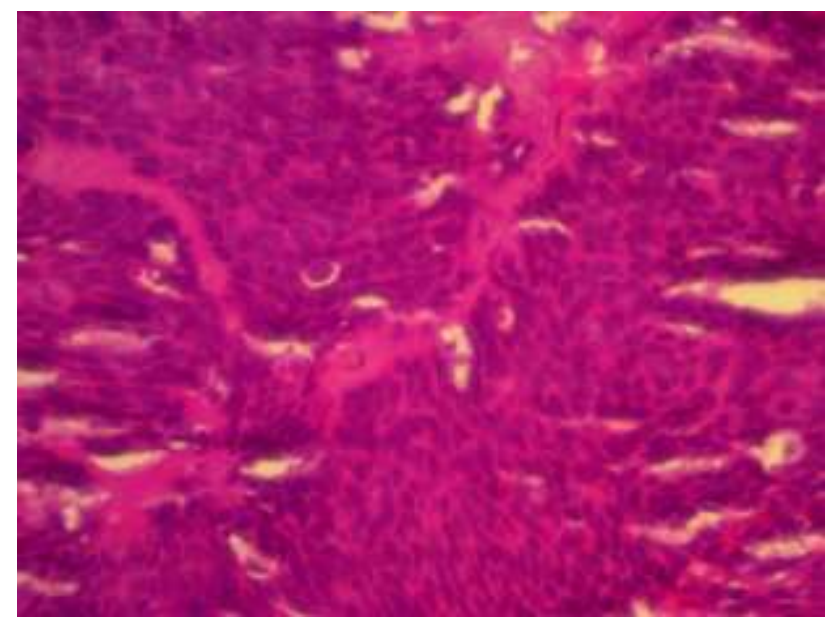

Figure 1: Tumor showing papillary core and transitional epithelium showing flattening at the upper most area $(400 x, H \& E)$.

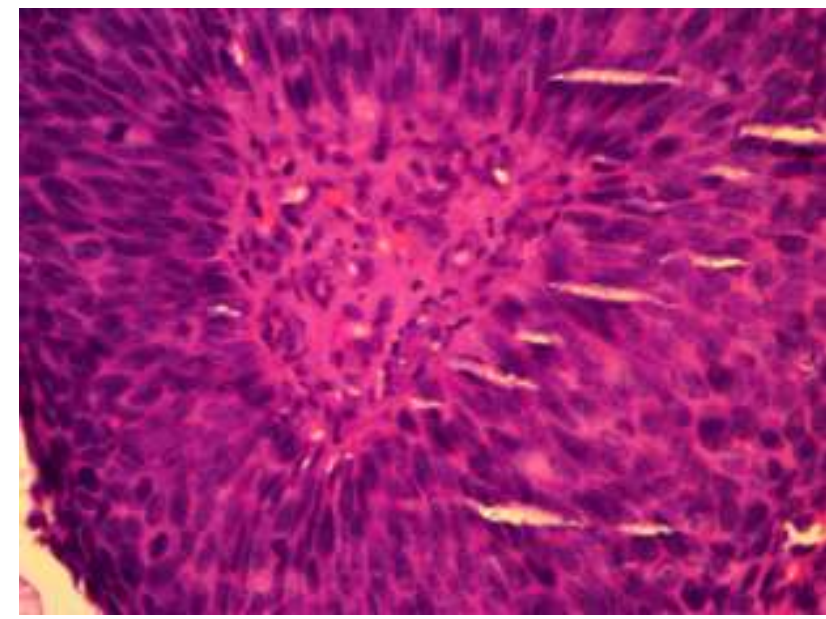

Figure 2: Tumor cells showing high N: C ratio with round to oval hyper chromatic nuclei, showing frequent mitotic figure $(\mathrm{H \& E}, 400 x)$.

Case 2

Cervical punch biopsy was sent for histopathological examination. All the sections studied showed tumour composed of neoplastic squamous cells arranged in papillary pattern with central fibrovascular core (Figure 2). Diagnosis of moderately to poorly differentiated invasive papillary squamous cell carcinoma of the cervix was given on histopathological examination.

\section{Case 3}

Cervical punch biopsy was received for histopathological examination. Microscopic sections from the tissue revealed moderately differentiated neoplastic squamous and transitional around fibrovascular core in papillary arrangement (Figure 3). Diagnosis was given as moderately differentiated invasive squamo-transitional cell carcinoma.

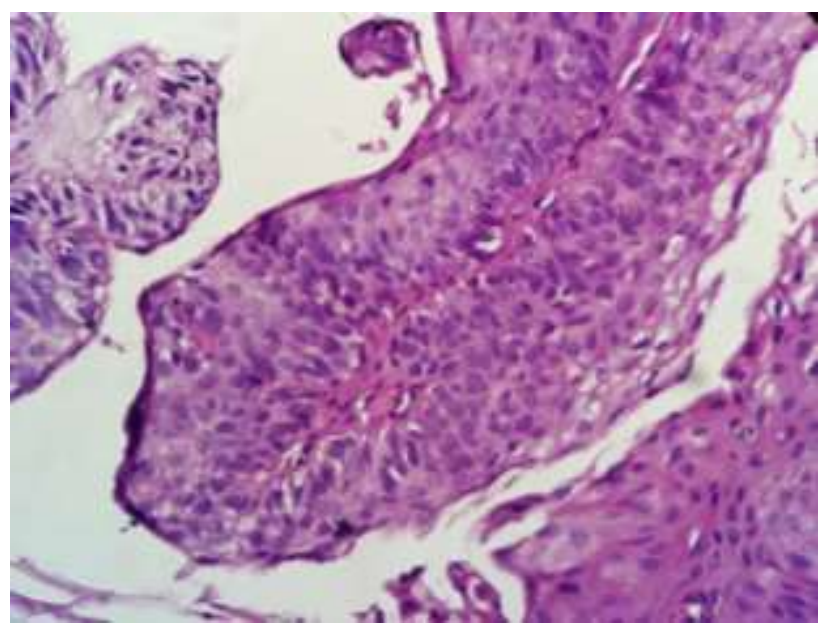

Figure 3: Tumor showing papillary configuration with multi-layering of cells (400x, H\&E).

Case 4

Cervical punch biopsy was received for histopathological examination. Microscopic sections from the tissue revealed moderately differentiated neoplastic squamous and transitional around fibrovascular core in papillary arrangement. Diagnosis was given as moderately differentiated invasive squamo-transitional cell carcinoma.

\section{DISCUSSION}

Papillary Squamous cell carcinoma of the uterine cervix is a rare subtype of cervical cancer and shows distinct clinicopathological features.

Incidence of the tumor has been reported as $1.6 \%$ of the cervical cancers. ${ }^{5}$ These tumors were initially identified by Marsh in 1952 and characterized as papillary squamous cell carcinoma by Randell et all in $1985 .^{6,7}$ The tumor occurs mainly in post-menopausal women. ${ }^{3,7}$ Our cases also presented in post-menopausal age.

Clinical presentation of this tumor is elderly women presenting with postmenopausal bleeding or abnormal Pap smear. 7,8 Our patients also presented with post- 
menopausal bleeding. These tumors are not diagnosed easily on colposcopic examination as tumor grows superficially with wart like exophytic growth. ${ }^{9}$

\section{Histopathological examination}

Papillary tumors of the cervix are divided into three groups based on histological appearance i.e. Predominantly Squamous, Predominantly Transitional, Mixed Squamous and Transitional. ${ }^{10}$ The tumor reveals papillary projections covered by atypical epithelial cells which show squamous or transitional cell differentiation. Tumor cells reveal hyperchromatic oval nuclei with scanty cytoplasm with frequent mitosis. Few cases can show cytological changes suggestive of human papilloma virus infection but none of our cases displayed such changes.

\section{Differential diagnosis}

Papillary Squamous cell carcinoma can be mistaken for Papillary squamous cell carcinoma in situ, Verrucous carcinoma or as Condyloma accuminatum. ${ }^{3,11}$

\section{Immunohistochemistry}

Majority of papillary squamous cell carcinoma of the cervix display the cytokeratin profile of squamous cell carcinoma of the cervix (i.e., CK7+/CK20-) in contrast to transitional cell carcinoma of the urinary bladder (CK7+/CK20+). ${ }^{12}$

\section{Course and prognosis}

The tumor is potentially aggressive and have tendency for late recurrences and metastasis. Six months follow up of our cases is uneventful.

\section{CONCLUSION}

Papillary squamous cell carcinoma of the cervix is a clinico-morphological distinct group of cervical lesions and displays a morphological spectrum.

As the tumor is potentially aggressive, should be distinguished from transitional cell carcinoma of bladder and other papillary lesions of the uterine cervix.

Funding: No funding sources Conflict of interest: None declared

Ethical approval: Not required

\section{REFERENCES}

1. Kokka F, Verma M, Singh N, Faruqi A, Yoon J, Reynolds K. Papillary squamotransitional cell carcinoma of the uterine cervix: Report of three cases and review of the literature. Pathology. 2006;38:5846.

2. Kaur A, Singh J, Bansal R, Kaur R, Bansal M, Kaur P. Transitional Cell Carcinoma: A Case Report with clinical, histological and cytological findings. JCDR. 2013;7(12):2954-5.

3. Al-Nafussi Al, AI-Yusif R. Papillary squamotransitional cell carcinoma of the uterine cervix: an advanced stage disease despite superficial location: report of two cases and review of the literature. Eur J GynaecolOncol. 1998;19:455-7.

4. Qizilbash AH. Papillary squamous tumours of the uterine cervix: A clinicopathological study of 21 cases. Am J ClinPathol. 1974;61:508-20.

5. Randall ME, Andersen WA, Mills SE, KimJC: Papillary squamous cell carcinoma of the uterine cervix: a clinicopathologic study of nine cases. Int Gynecol Pathol. 1986;5:1-10.

6. Marsh MR. Papilloma of the cervix. Am J Obstet Gynecol. 1952;64:281-91.

7. Albores-Saavedra J, Young RH. Transitional cell neoplasms (carcinomas and inverted papillomas) of the uterine cervix. A report of five cases. Am J Surg Pathol. 1995;19(10):138-45.

8. Koenig C, Turnicky RP, Kankam CF, Tavassoli FA. Papillary squamotransitional cell carcinoma of the cervix: A report of 32 cases. Am J SurgPathol. 1997;21:915-21.

9. Nagaraj TS. Papillary Squamous Cell Carcinoma of Cervix: A case report with review of literature. Int $\mathbf{J}$ Intg Med Sci. 2014;1(1):14-6.

10. Witkiewicz AK, Wright TC, Ferency A, Ronneth MB, Kurman JR. Carcinoma and other tumors of the cervix. In Blaustein's pathology of the female genital tract, Kurman JR, Ellenson LH, Ronnett BM, 6th edition, Springer, 2011:271-272.

11. Mirhashemi R, Ganjei-Azar P, Nadji M, Lambrou N, Atamdede F, Averette HE. Papillary squamous cell carcinoma of the uterine cervix: An immunophenotypic appraisal of 12 cases. GynecolOncol. 2003;90:657-61.

12. Anand M, Deshmukh SD, Gulati HK. Papillary squamotransitional cell carcinoma of the uterine cervix: A histomorphological and immunohistochemical study of nine cases. Indian J Med Paediatr Oncol. 2013:34:66-71.

Cite this article as: Patil NJ, Shukla DB, Bharti M, Mehta M. Papillary squamotransitional carcinoma of cervix: a series of four cases. Int J Reprod Contracept Obstet Gynecol 2016;5:1820-2. 